\title{
WestVirginiaUniversity
}

THE RESEARCH REPOSITORY @ WVU

West Virginia Agricultural and Forestry Experiment

Davis College of Agriculture, Natural Resources

Station Bulletins

And Design

1-1-1909

\section{Cabbage Worms and Suggestions for Destroying them}

\author{
W.E. Rumsey \\ Fred E. Brooks
}

Follow this and additional works at: https://researchrepository.wvu.edu/ wv_agricultural_and_forestry_experiment_station_bulletins

\section{Digital Commons Citation}

Rumsey, W. E. and Brooks, Fred E., "Cabbage Worms and Suggestions for Destroying them" (1909). West Virginia Agricultural and Forestry Experiment Station Bulletins. 120.

https://researchrepository.wvu.edu/wv_agricultural_and_forestry_experiment_station_bulletins/120 @ WVU. It has been accepted for inclusion in West Virginia Agricultural and Forestry Experiment Station Bulletins by an authorized administrator of The Research Repository @ WVU. For more information, please contact ian.harmon@mail.wvu.edu. 

WEST VIRGINIA UNIVERSITY

AGRICULTURAL EXPERIMENT STATION

MORGANTOWN, W. VA.

\section{Cabbage Worms}

A N D

\section{Suggestions for Destroying Them}

By IV. E. RUMSEY AND FRED E. BROOKS.

(The Bulletins and Reports of this Station will be mailed free to any citizen of Wcst Virginia upon written application. Address Director of Agricultural Experiment Station, MIorgantown, IV. Va.) 
Name of Regent

P. O. Address

Hox. C. M. Babe.

Falls, W. Va.

Hon. J. B. Finlet . . . . . . . . . . Parkersburg, W. Va.

Hon. D. C. Galiaher..................

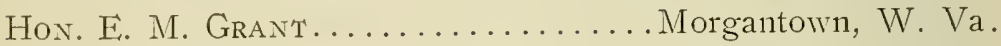

Hon. C. E. Haworth ...............Huntington, W. Va.

Hon. C. P. MCNELL.................Wheeling, W. Va.

Z. F. Vinson .................. Huntington, W. Va. Hon. T. P. Jacoss.............. New Martinsville, W. Va.

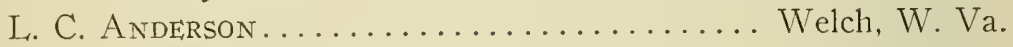

President of the Board of Regents........... M. BABB President of the University............. B. Purinton

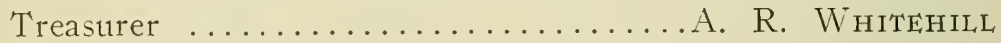
Auditor $\ldots \ldots \ldots \ldots \ldots \ldots \ldots \ldots \ldots \ldots \ldots$ W. J. WHITE

\section{STATION STAFF}

JAMES H. STEWART, A. M......... Director and Agriculturist BERT H. Hit'E, M. S.............Vice Director and Chemist IV. M. Munson, Pr. D................... Horticulturist WT. E. Rumsfy, B. S. Agr. . . . . . . . . . . Entomologist

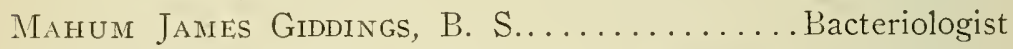
Horace Atwood, M. S. Agr........... Assistant Agriculturist

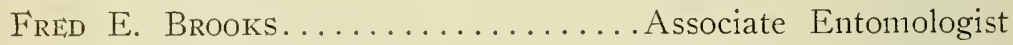

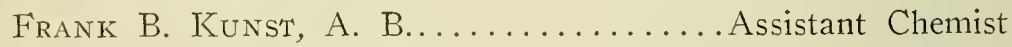

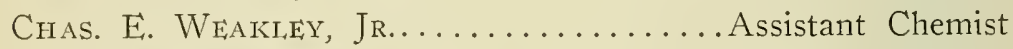

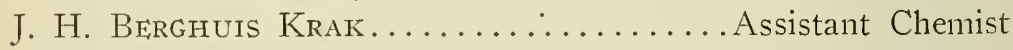
A. L. DACY, B. Sc................ Assistant Horticulturist

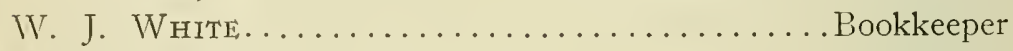

M. A. STEWART . . . . . . . . . . . . . L Librarian

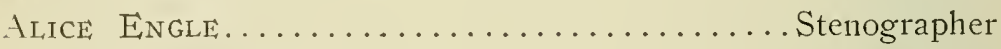

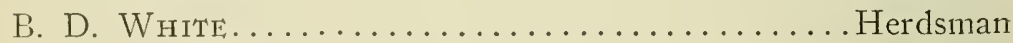

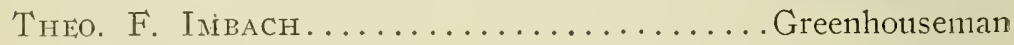


The last session of the Legislature appropriated money for the promotion of horticultural and trucking industries of the State. This is a very commendable undertaking by the Legislature and the duties of carrying out the work have been imposed upon the Director of the Experiment Station. Among other things, in pursuance of the Act of the Legislature, a series of bulletins upon practical subjects bearing upon horticulture and trucking will be published from time to time and this bulletin is the first of the series.

In carrying out the work the hearty cooperation of all persons engaged in trucking and in horticulture is cordially invited.

Yours truly,

J. H. Steiwart. 

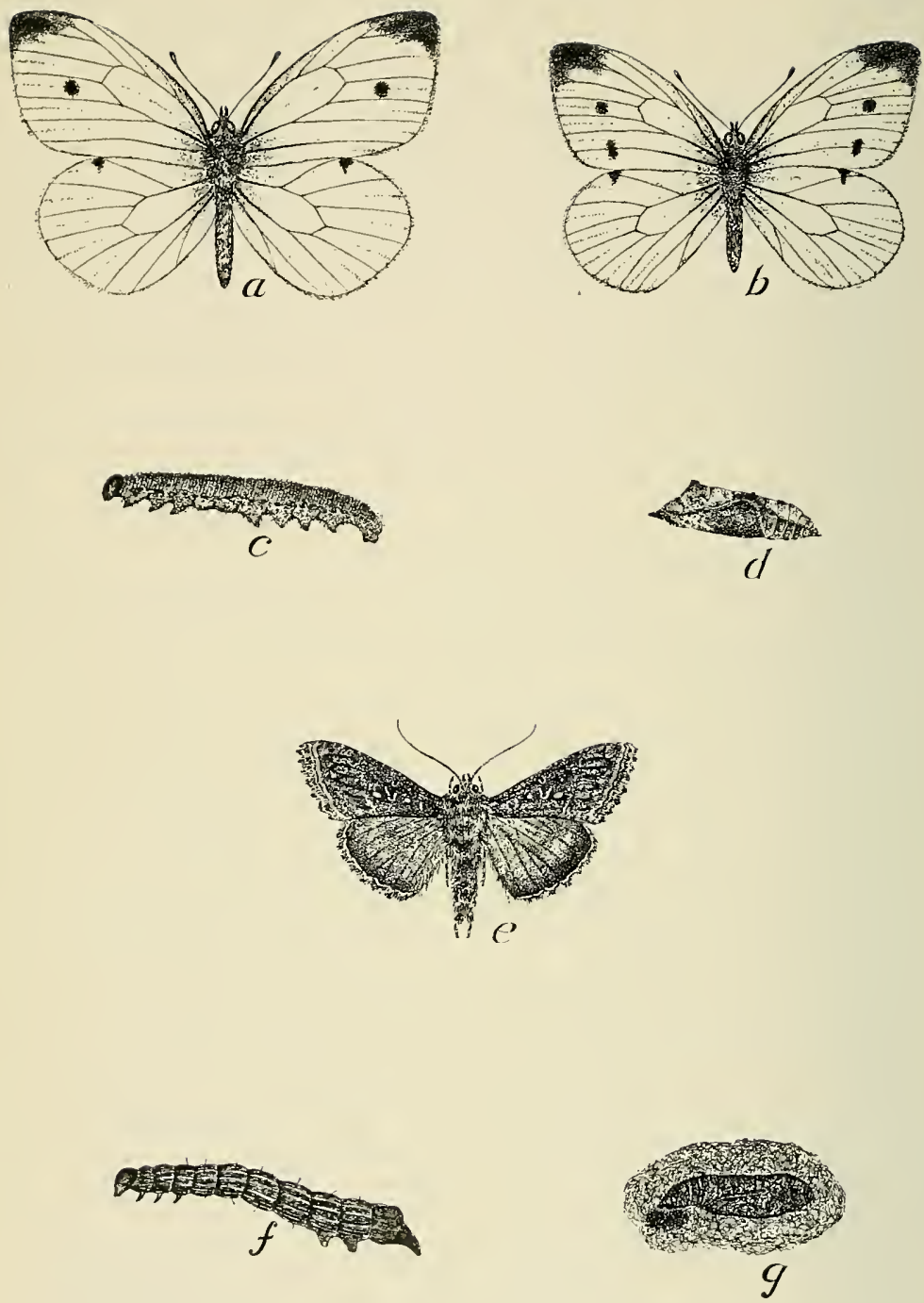

$a$ and $b$, Imported Cabbage Butterflies, male and female; c. larva: $a$, pupa; $e$, Cabbage Looper; $f$, larva; $g$, pupa in cocoon. All natural size. Drawings by A. B. Brooks. 


\title{
Cabbage Worms and Suggestions for Destroying Them
}

\author{
IN'TRODUC'TION.
}

For several years the growing of cabbage in II est Iirginia, in both market and family gardens, has been greatly discouraged by the abundance of "cabbage worms." Not many years ago we had areas of considerable extent in several sections of the state devoted to this crop. In the valleys of the Ohio and Great Kanawha rivers and in some of the eastern connties cabbage was produced and sold in local markets at a good profit to the growers. Now, very largely as a result of injury by worms, cabbage growing has greatly decreased and in some sections has been almost entirely abandoned. The markets for this vegetable are constantly growing better, both as to the fuantities required and the prices paid, but they are supplier almost wholly with cabbage grown outside the state. The same insects that have discouraged the production of cabbage here are present in the trucking regions from which our present supply comes but growers there have learned how to deal with them and as a result are able to monopolize our markets to the serious loss of our own farmers.

The spray pump and arsenical poisons form the combinations which outside truckers have used to force our farmers out of the cabbage business. Spraying is now almost universally practiced wherever large fields of cabbage are successfully grown. In fact, it is next to impossible to grow cabbage at a profit anywhere. in the United States without spraying. The principal reason that this method has not come into more general use here is that there very naturally exists among constumers, dealers and even the growers, a belief that it is not safe to use cabbage after it has been sprayed with a poison. In one or two cases cabbage growers along the Ohio river have sprayed their 
plants but when they tried to market their crop near home the dealers refused to buy because the cabbage had been sprayed and they feared the consequences to their customers. These dealers afterward laid in their supplies from other sources with the probable result that they got cabbage that had been sprayed repeatedly with the identical poisons used by the local trucker.

It seems unfortunate, and unnecessary, that we should continue to purchase this important article of food from other states when we have excellent soils and other facilities for growing it here and when by using the same methods against insects that are practiced elsewhere we can supply all our own needs and those of some of our neighboring states and at the same time furnish a source of substantial income to many of our farmers and truck growers.

Before cabbage growing can be engaged in successfully as a commercial enterprise, however, the people must understand that cabbage, after having been sprayed in a proper manner to kill the worms, may be eaten without any danger of poisoning to the consumer. Of the thousands of acres of cabbage that are sprayed every year in this country we have not been able to find that there is a single case of poisoning resulting therefrom on record. The writers would not underestimate the extreme importance of exercising care at all times in handling poisons but they believe that anyone who can attend to the spraying of fruit tree's and potatoes successfully can perform the same work in the cabbage field with entire safety to all persons concerned. Several reasons may be mentioned why such spraying is not dangerous. In the first place, the worms are highly susceptible to poisons and a very dilute mixture is strong enough to kill them. After the head of the cabbage plant begins to form any spray that is applied to it falls only on the outer leaves. These leaves, as everybody knows, are trimmed away in preparing the head for use, leaving only that part of the plant to be cooked that has not been touched by the poison. As the head forms from within there is no possibility that the liquid of the spray can penetrate into the edible part. Rains occurring after 
the sprayings wash most of the poison away and even when no rains fall it has been found that the poison disappears from the cabbage leaves within two or three weeks after the application.

The chief ain in sending out this bulletin is to stimulate a judicious but more general use of the spray pump in the production of cabbage in West Virginia. The benefits to be derived from spraying fruit trees, grapevines, potatoes and some other crops are already well known to the public and we believe, that by following the directions given in this publication the practice can just as advantageously be extended to cabbage. We have deemed it best to describe a few methods, in addition to spraying, which are of value in combating cabbage worms for the benefit of those who may hesitate to apply poisons to the plants until they have given the matter further investigation.

The source from which the different kinds of worms come in such numbers to attack cabbage is not always clear to growers and we give the following brief descriptions of the habits and life-histories of several species found in this state.

\section{DESCRIPTIONS OF DIFFERENT SPECIES OF CABBAGE WORMS.}

The worms that feed on the leaves of cabbage are the larvæ of numerous species of butterflies and moths. A great many different kinds of such larvæ have been recorded as being injurious to cabbage in the United States but we have noticed but five species in this state. Of these three are butterflies and two are moths. There is little doubt that further study will reveal several other species of these insects as being occasionally or locally injurious to cabbage.

ThE IMPORTED CABbage Worm, Pieris rapae Linn. This butterfly was introduced into America from Europe about 50 years ago and has now become our worst enemv of cabbage. Its first appearance on this continent was in Canada but it spreaci rapidly, soon invading the United States, and now it is distributed over the entire country. It is abundant in all the farming sections of 
the state and the adult insect wanders through fields and forests in scarch of cabbage and other cruciferous plants on which to lay its eggs. In the summer of 1904 we caught one on the forest-covered bank of the Cranberry river, in Nicholas county, fourteen miles from any human habitation. It is one of the first butterflies to appear here in the spring, frequently being abroad in March and is often seen as late as the last of October.

This butterfly is one of the most familiar insects of summer. It is of medium size, expanding about twu inches, and is white with the wings tipped with black. The female has two black spots on each fore-wing and the male has one. Like most butterflies, this species loves warmth and sunshine and during bright summer days it may usually be seen in great numbers fluttering about over gardens and cabbage fields.

The worms or larvæ are velvety-green and when full grown measure about an inch and a quarter in length. The first eggs are laid early in the spring and the worms hatch from them in a week or less. They begin to feed at once, eating round holes through the leaves. The first brood of larvæ frequently develop on mustard or some other plant of the cabbage family. The outer leaves of cabbage are attacked first but as the plant grows and the head begins to form the inner and more tender leaves are preferred. The worms feed voraciously and deposit excrement in unsightly masses upon the leaves.

When the worms are full grown they transform to butterflies by going through a chrysalis stage. The chrysalides may often be found suspended by two threads of silk from the cabbage leaves but are also found on fences and other objects in the vicinity of the cabbage plants. There are at least three generations of the butterflies each summer and the winter is passed in the pupa or chrysalis stage.

On the leaves of cabbages that are infested with worms there will frequently be found collections of minute cocoons which resemble in shape but are smaller than a grain of rice. Some of these cocoons are sulphur-yellow and others are white. 


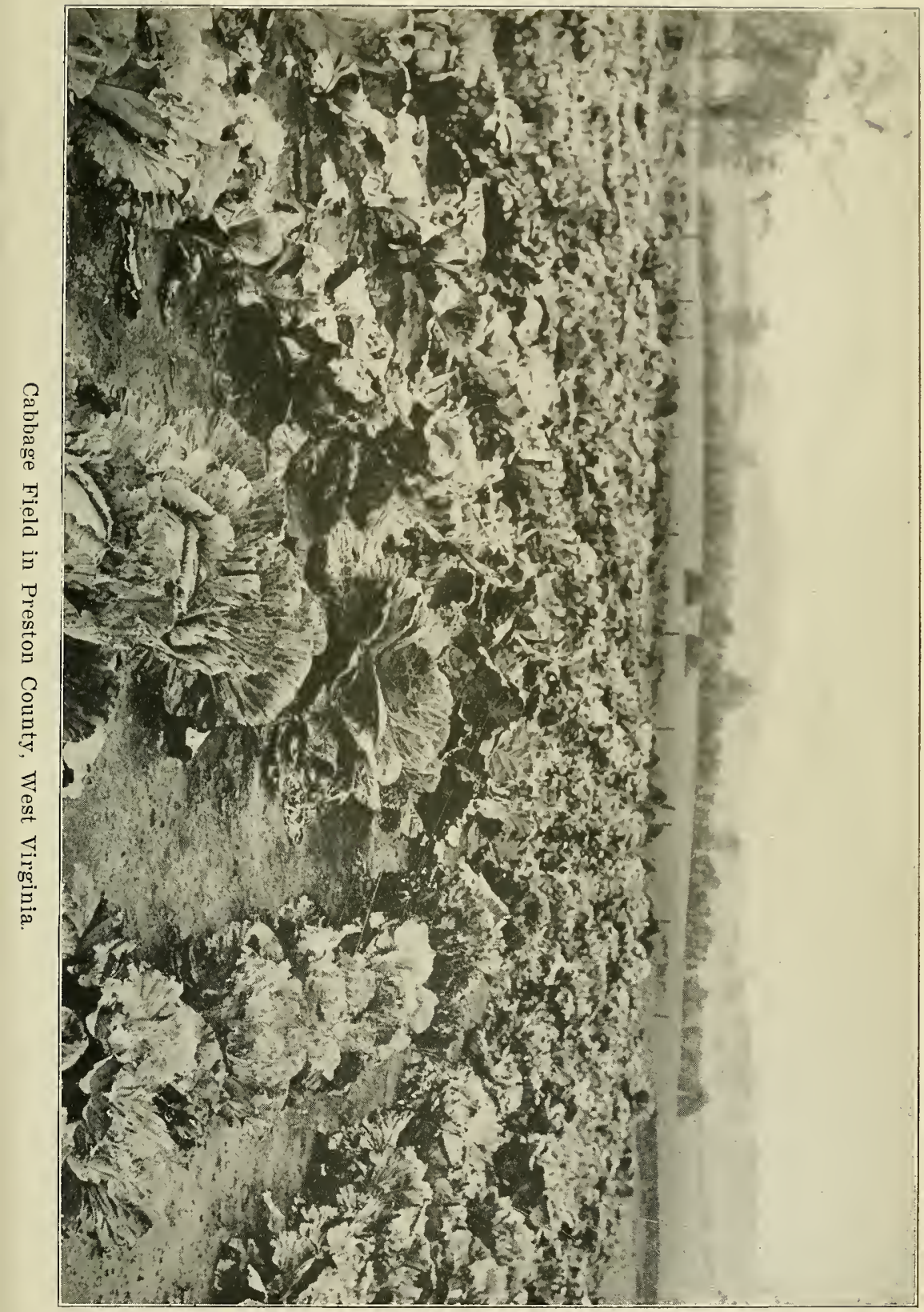



These should never be destroyed for from them emerge small, four-winged parasites which deposit their eggs on the cabbage worms and thus cause their destruction.

\section{The Southere Cabenge Butterifly, Pieris protodice} Baisd. This is a native butterfly that resembles in appearance and habits the imported species just described. The male is very similar to the foreign species but the female has the wings more heavily spotted and mottled with dark. Since the imported butterfly has taken possession of the country this native has almost entirely given place to it in many sections. It is still common, however, in the lower portions of the state and fur several years has been excessively abundant along the Ohio and Great Kanawha rivers, about Morgantown and perhaps at other points. It occasionaly, though rarely, ranges into the higher and more mountainous parts of the state. In many years collecting at French Creek, in Upshur county, we have never seen a specimen but in August, I904, we took one in an open, grassy spot in the great forest near the head of Cherry river at an elevation of about 3500 feet.

The larva is distinct from the imported species, being pale or dark blue, or sometimes green, striped with yellow and covered with black spots. They are most often found on cabbage. though like the other members of this group of butterflies they often feed on other plants of the cabbage family.

The Potherb Butterfliy, Pieris napi Linn. This is another native butterfly that has greatly decreaser in numbers since the advent of the foreigner. In its several forms it is distributd from the Atlantic to the Pacific and from Alaska to the Gulf States.

The butterfly is almost pure white. It is about the size of the other two and while on the wing can scarcely be distinguished from them, but when examined closely the differences are easily seen. The worms are pale green and it is probable they attack wild plants more often than cabbage. The butterflies frequent 
open woods rather than fields. We collected several in the woods near Morgantown in April and May, 1905-06. In May, I893, Dr. A. D. Hopkins collected a number in Pocahontas county.

The Cabbage Looper, Autographa brassicae Riley. The larva of this moth as it rests upon the cabbage leaf can easily be mistaken for that of the imported cabbage butterfly. It lacks the velvety appearance, however, and there are parallel lines of paler green running along the back. When it crawls about it "humps" itself, after the manner of the measuring worms, a movement unlike that of any of the butterfly larvæ. When the worms are full grown they spin fragile cocoons on the underside of the cabbage leaves inside of which they transform to moths. The moths are dark colored with numerous markings of lighter shades on the fore-wings. They are shown natural size in the frontispiece of this bulletin. Several generations occur each season and the insect is one of the worst pests of cabbage found in the state.

The Cross-Striped Cabbage, Worm, Evergestis rimosalis Guen. The larvæ of this moth have been found attacking cabbages in several places in West Virginia. In some sections it rivals the imported cabbage worm and the cabbage looper in the extent of its damages. The worm is about three-fourths of an inch in length when full grown. The body is purplish-brown above with several transverse lines of white. A yellowish line extends along each side. When ready to pupate the worms leave the cabbage and descend to the surface of the ground where they change to moths. The adult moth is less than an inch in expanse and is prettily marked with mottlings of yellowish brown. The base of the hind-wing is almost transparent.

METHODS OF CONTROL.

Paris Grecn. By far the easiest, cheapest, and most effective method of destroying cabbage worms is by the use of Paris green. This material is used in the proportion of one pound to $200 \mathrm{gal}-$ 
lone of water and slould be applied to the plants, for best result. in the form of a mist spray. The first application shoull be madesoon after the plants are transplanted and should be repeaterl at intervals of about three weeks. This treatment may be continued until three or four weeks before the cabbage is harvested Since the worms feed on both the upper and under surfaces of the leaves care should be taken to direct the spray against all the exposed parts of the plant. This poison is sometimes combinerl with flour and dusted onto the plants with good results

By way of strengthening what has already been said in regard to the safety of eating cabbage that has been sprayed with Paris green, we wish to quote from some of the leading Entomologists of the country whose wide experience in dealing with insects that affect garden vegetables enables them to speak with authority on this subject.

Dr. F. H. Chittenden, U. S. Dept. of Agriculturc. "The best remedy is one of the arsenicals; and Paris green and arsenate of lead are preferred to others in common use. If the former is used it may be applied either dry or wet, preferably, however, as a spray, at the rate of one pound of poison to I 50 gallons of water. It should be applied when the plants are first set out, so as to insure the poison reaching the young larvæ before they have burrowed far into the heads. Other applications should follow as required. These can be made with absolute safety until the heads are about half formed, and, for that matter, even later, as the poison disappears from the plants almost completely within three or four weeks after the application. Chemical analysis has shown that cabbage which has been dusted or sprayed with an arsenical in the way prescribed, and then prepared for cooking a week later, has not even a trace of arsenic remaining. The use of arsenicals against cabbage worms is almost universal in the United States, although growers are sometimes loath to acknowledge the fact for fear of the loss of customers who are not fully acquainted with the harmlessness of the remedy. There are no authentic recorded instances known to the writer of, poisoning from the consumption of cabbage 
treated with an arsenical." (Cir. No. 6o, Bureau of Entomology.)

Prof. J. B. Smith, State Entomologist, Neau Jersey". "The cabbage heads from within, - that is to say, the leaves unfold from the center of the head and do not fold together to form it; therefore, whatever poison is put upon the plant can fall only upon the outer leaves, and not a particle gets into the head itself. The amount used to a single cabbage-plant is so minute that in order really to poison a man it would be necessary for him to eat about a dozen heads, outer leaves and all, and if death then resulted I would be inclined to attribute it rather to the cabbage itself than to the Paris green or other arsenite employed. The larvae succumb to the poison very readily, and by making the application early in the season the later broods may be materially reduced in number. In ordinary farm practice the heads are cut out and shipped, and in preparing the cabbage for food, the outer leaves, of these heads are usually taken off by the housewife because more or less bruised or injured, before they are cooked. Chemical analysis has shown that on a head so prepared, within a week after a heavy application of Paris green, not a trace of arsenic remained. . As a matter of fact, the use of Paris green as against the insect is quite common, although little is said of it, to avoid exciting prejudice, and I have yet to learn of the first case of arsenical poisoning from eating cabbage so treated." (Economic Entomology, page 248.)

Keroscne Emulsion. This material if applied to the plants in the form of a spray will kill the worms but it is less effective than the arsenicals. It should be used at a strength of one part of the emulsion to twelve or fifteen parts of water.

Pyrethrum. This powder is a good contact poison for in-. sects but will not poison humans. If applied often to infested cabbage it will kill the worms but it is much more expensive than Paris green. It is said by some growers to discolor the cabbage leaves. 

